Research.

\title{
Analysis of the factors determining social media instragram as promotion media on the online shop in DKI Jakarta area
}

\author{
Restu Hazar ${ }^{1^{*}}$, Resista Vikaliana ${ }^{2}$ \\ ${ }^{1 *}$ Business Administration, Institute of Social Science and Management STIAMI \\ ${ }^{2}$ Management, Institute of Social Science and Managemetn STIAMI \\ ${ }^{1 *}$ restuhazar@gmail.com, ${ }^{2}$ resistav31@gmail.com \\ * Corresponding author
}

Received: Mart 25, 2020; Accepted: April 12, 2020; Published: June 30, 2020

To cite this article: Hazar, Restu, and Resista Vikaliana. 2020. Analysis of the factors determining social media instragram as promotion media on the online shop in DKI Jakarta area. The Management Journal of BINANIAGA. 5 (1): 11-22. doi: 10.33062/mjb.v5i01.371

\begin{abstract}
Social media is basically regarded as one kind of communication media. Social media in general is a medium used to socialize (connection, either personal or group and so on) among the users, it is not any exception, Indonesia's business community is Instagram social media. Instagram is one of the social networking apps used to share photos and videos that allow users to take photos and share them with followers. This way is used by online shop to promote its products. This study aims to determine and analyze the factors that determine Instagram social media as a campaign media on the online shop 1) Cognitive, 2) Affective, 3) Personal Integration, 4)Social Integration, 5) Release Tension, 6) Accessibility, 7) Relative Cost, 8) Life Style Envy about 3 online shops @elzattahijab, @zoyalovers, and @rabbaniprofesorkerudung_shop which are selling or offering women's clothing. This research uses descriptive qualitative method. Informant in this research is divided into 2 (two) that is key informant and main informant. Data analysis using comparative constant model The process of data analysis includes data reduction, data category, and sisntesisation. The 8 (eight) factors that determine social media Instagram as media promotion on the online shop and there are 7 (seven) factors that determine the online shop@elzattahijab, @zoyalovers, and @rabbaniprofesorkerudung using Instagram as a media campaign on their online shop which is, cognitive, affective, personal identity, social identity, release of tension, easy accessibility, relative reasonable cost factors. For life style envy or jealousy lifestyle, online shop does not feel this factor has become one of the use of social media Instagram as a media campaign on their online shop. And researchers have found one factor that become online factor shop @elzattahijab, @zoyalovers, and @rabbaniprofesor kerudung using Instagram as a media campaign, the innovation feature on Instagram is Insta Stories and live broadcast.
\end{abstract}

Keywords: Promotion, Instagram, Online Shop

\section{INTRODUCTION}

\section{Background}

Basically, social media is corresponding to a communication media. As a matter of fact, all the people are connected with social media recently. They are using it for the purpose of working, chatting with relatives or friends, old friends and dealing with business. Overall, social media and social network have applied online media connected with internet. Social media and social network have made people interact each other unlimitedly 
either demographics, space or time, to share information or things, to make friends, and in some cases they are looking for a partner for living as well as running a business. Marketing using social media is a social media marketing. Social media marketing is an effort to perform an online marketing which is visibility and existency marketing appearing on web site social media network such as Instagram, Facebook, Twitter, Digg, Web 2.0, social bookmarking, etc.

Referring to the research of Criteo (a company of marketing performance technology Q3 2016 State of Mobile Commerce Report), Indonesia has taken the first place in Asia Pacific which is using smartphone to deal with online transaction of $68 \%$ defeated Taiwan which is $60 \%$. This survey has triggered the people to speed up marketing their products using online shopping or social media which is Instagram. Instagram is an application of social network to share photos and videos. It is applying applicable digital filter sharing with other social network which is facebook. It was developed by Instagram in 2010, and recently instagram has been the most social network downloaded and applied in Indonesia. It has made alot of producers which are insterested in marketing their products in Instagram social networking.

Alot of online shops have been offering and promoting various products required by the people in the Instagram social network. Online shop is a kind of business interested by mostly business people due to rapid development and easy to use as promotion and marketing media. . Online shop is trading activities performed by producers and customers without phisical meeting. Products are offered in pictures or videos in the internet. Many customers who do not have enough time can purchase their needs using online shop which is a big help for them.

Referring to the data on Facebook Indonesia, total of Instagram users in Indonesia up to July 2017 had reached 45 million users, and $80 \%$ of them had been joining at least one business account and $1 / 3$ of the contents on the Instagram were business accounts. It has proved that Instagram has taken a big role to support business development in Indonesia. Promotion done by online shop can ease the customers choosing the products offered anytime and any places, and it is time reducing. Promotion technique on the online shops is more effective and efficient since the price offered is reasonable and affordable comparing to direct buying at a mall or store. Instagram has made the owner of online shop enable to provide information to the customers and build up strong relationship between branded products and customers. Some online sellers have used the benefit of Instagram social network as a promotion media by having a lot of followers which are joining their account on the online shop. Thru Instagram, online shop owners are able to observe and to evaluate the customers' need and requirement so that they can provide the products and response the customers requirement.

This research has identified the extent to which factors of online shop account has applied Instagram social media for the purpose of promotion media by comparing with other online shop accounts which is the shops that are having the same type of Moslem Fashion. Based on the developing phenomena on Instagram social media about online shop accounts that are selling moslem fashion products, the writer has noted some online shop accounts that have been evolving rapidly and having quite a lot of their followers such as @elzattahijab, @zoyalovers, @rabbaniprofesorkerudung. Nevertheless, aims of this research are to figure out the extent to which the factors determining Instagram social media application as promotion media on the online shop.

\section{LITARATURE REVIEW}

\section{Previous Research}

Previous research is the researcher effort to figure out the research comparison and further more to find out a new inspiration for the following researchers, however, previous research is helping this research to show up its origin.

Restu Hazar and Resista Vikaliana. Analysis of the factors determining social media instragram as promotion media on the online shop in DKI Jakarta area

Page : 12 
In this part, the researcher has identifed some previous researches corresponding to this research, and to create a summary of either the research was published or not yet published (scripts, thesis, disertation. Etc) by doing this step, it can identify the extent to which the originality and position of the research is.

1. First, is the research of Deru R. Indhika and Cindy Jovita(University Pajajaran) in June 2017 in a Journal with the topic of "Social Media of Instagram as Promotion tools to increase the consumers' purchasing intention". This research is about how Instagram as a social media can affect the intention of customer to buy tourism desitination offers. Subject of this research is Floating Market in Lembang, Bandung, West Java. And Result of the research has identified that the information using Instagram is effective to increase the intention of customers to buy which is $50.2 \%$.

2. The second one is the research of Dewi Kurniawati and Nugraha Arifin (University of North Sumatera) in 2015 in a Journal with the topic of "Marketing Strategy using Social Media and the willingness to buy of the students". This research is to find out the correlation between the strategy of marketing communication of Brodo Footwear in the Instagram and the willingness to buy of the students at the University of North Sumatera(USU). Result of the research has identified that there is a low but significant correlation between marketing strategy of Brodo Footwear and the willingness to buy of the students at FISIP, Universtity of North Sumatera.

As mentioned before, the researcher has described that the previous researches are to determine the position of the research that will be done. However, this research has had either similarity or different with the previous researches. The similarity of the research is on the data collection technique and the object of the research determining Instagram social media as an effective onlineshop promotion media. And the difference of this research with the previous ones is on the theory application and research method. This research has applied descriptive research method using qualitative approach. Nevertheless, the previous researches have applied different method using quantitative method.

\section{Marketing}

\section{Marketing Definition}

According to Miller and Layton (2009:2), "Marketing is total business activity system corresponds to planning, pricing, promotion and product distribution, service and idea that can make the market satisfied in order to reach the organization goals. For the marketer, the promise to make the customers satisfied thru marketing mix can reach a long-term profit though sometimes it has to sacrifice a short-term profit."Customer satisfaction is the differences between expectation and performance or result obtained". (Tjiptono and Chandra, 2008:24).

\section{Marketing Mix}

Referring to Kotler and Keller (201:47), "Marketing mix is a set of company's marketing tools being used to pursue the marketing objectives in a certain market target". Marketing mix is consisting of all the things that company uses to influence its product demand. Marketing mix is the core of marketing system. Analysis about marketing mix is important to be executed in order to make the market demand is complying with the products supply. Varied possibilities can be categorized into 4 variable groups which is $4 \mathrm{P}$, Product, Price, Place and Promotion.

a Product is a thing or service combined by the company to be introduced into a prospect market targeted. It is covering Product Variety, Quality, Design Feature, Brand Name, Packaging Warranties, Size, Service and Return.

b. Price is a certain amount of money that should be paid by a consumer to get the product or service. It is covering price list, discount, terms of payment, credit facilities.

Restu Hazar and Resista Vikaliana. Analysis of the factors determining social media instragram as promotion media on the online shop in DKI Jakarta area 
c. Place / distribution, it is including activities of the company that has put the product reaching the consumers. It is covering distribution, coverage, location, stocks, transportation and logistics.

d. Promotion is the activities to communicate varied superiority of the products, and to influence prospect market to buy the products using advertisement, individual selling, marketing promotion and social relationship.

\section{Promotion}

Referring to Alma (2012:179), 'Promotion is a kind of communication convincing a prospect customer about the product/service description offered". Promotion is one of the factors that makes marketing program success. Eventhough, how good the quality of the product is introduced but if the customers have not heard yet about it before, and, they do not believe that the product offered is usefull for them, of course,, they will never be willing to buy. "Main objective of the promotion is the way how to inform, influence and persuade the prospect customers about the company corresponding with marketing mix" (Hurriyati, 2008:58). Objective of a promotion can be described in detail as the following:

a. Informing,

b. Persuading,

c. Reminding, It is consisting of reminding the customer that the product is required in the near future, reminding the customer the place of the product, making sure that the customer will remember the product offered eventhough there is not any advertising campaign and maintaining the customer intention to buy the product offered. Though, in general, promotion types have had equal function, but it can be differentiated based on its specific task. Some particular tasks are named promotion mix.

\section{a. Promotion Mix}

Promotion mix is also called marketing communication mix of the company which is a specific advertisiment of marketing promotion to communicate the value of customer persuasively and to build up the relationship with the customers. Referring to Kotler and Armstrong (2010:174), "Promotion Mix consists of eight elements or promotion mix method as the following":
1) Advertising,
2) Personal Selling,
3) Sales Promotion,
4) Public Relations,
5) Direct Marketing,
6) Interactive Marketing,
7) Mouth of Mouth,
8) Event \& Experience.

\section{b. The Factors Influencing Promotion Mix}

Referring to Swastha and Irawan (2008:355) there are some factors should be considered which is influencing the Promotion Mix as follows:
1) Type of Product Market .
2) Push strategy against Pull strategy
3) Buyer Stage Readiness.

c. Online and Social Media Marketing Promotion

According to Kotler and Keller (2016:22) "Online and social media marketing

Restu Hazar and Resista Vikaliana. Analysis of the factors determining social media instragram as promotion media on the online shop in DKI Jakarta area 
is online activites and programs designs to engage customers or prospects and directly or indirectly raise awareness, improve image, or elicit sales of products and services".

Using electronics media for a certain brand is a communication tool to transfer the information about suppliers and product description to the customers thru online shopping applying internet technology such as, Facebook, Twitter, Instagram and other social media (Kshetridan Jha, 2016:35). Social media is a technology network being used to create a news to internet users and to communicate it by spreading the information, but, social media marketing is a kind of internet marketing model to reach marketing goals by participating with social media networking. (Trusov on Kshetry and Jha, 2016:95).

\section{Social Media}

\section{a. Social Media Definition}

Febriyansya (Napitupulu, 2013:10) described that social media definition has been expanded, social media is a democratisation of information which is changing a person from a reader to be a writer. It is a movement of news mechanism based on chatting between the writer with someone or a friend. Based on the definition above, it has described fundamental elements of social media, as follows:

1) Social media has involved varied social channel and online channel to become a main channel.

2) Social media has been changing from time to time, it means that social media has been developing to be better.

3) Social media is participative media. The audiences are considered creative that can issue their comment or publish their own content.

\section{b. Characteristics and Types of Social Media}

Evans (Napitupulu, 2013:51) described, Type of social network or social media divided into six types:

1) Social News Sites, This social media is allowed the users to send a news, information, article, photo and video which are going to be evaluated (vote like or dislike). Such as Digg.com or Reddit.com that are worldwide social news platform.

2) Social Networking, is the most popular social media in Indonesia, it has begun with Friendster ear, and continued by MySpace.com and moreover it is becoming the most popular social media worldwide such as Facebook and Instagram. These webs are allowed the people to create personal web.page connected to their friends to communicate and to share their contents.

3) Social Sharing is some network platform or social media focusing on the features about content sharing, the popular things are Youtube, Flickr, Souncloud. The main function of them are allowing the users to be recognized quickly in the cyberspace as long as they have loveable and unique contents.

4) Blog, is a network or social media allowing the people to actualize themself by issuing an article, idea, opinion, story, and information on it. Such as Blogspot.com and wordpress.com.

5) Microblogging, is a network or social media which is having a limited space to write a message or content. Such as Twitter that is allowed only writing 140 characters to write a message.

6) Internet forum, is the pioneer of recent network or social media.

\section{Instagram}

\section{a. Definition and the History of Instagram}

Instagram is coming from the word of insta or instant. Instagram can demonstrate photos instantly as polaroid features. And the word 'gram' which is

Restu Hazar and Resista Vikaliana. Analysis of the factors determining social media instragram as promotion media on the online shop in DKI Jakarta area 
coming from the word of telegram that is sending information to other people very quickly. Instagram is able to upload photos and videos using internet network, so that, the information can be sent and received rapidly.

Instagram is created by Burbn, Inc. A corporation which is based on a startup technology and focusing on the handphone application development. Both CEO Instagram, Kevin Systrom and Maike Krieger had been starting to produce a good idea within a week and finally they had made the first version from Burbn, however, there was still some issue which was not perfect in this first version. Since it had been introduced on October 6th, 2010, the final version of Burn is the application that can be applied on the Iphone where the contents have had much features. It was very hard for Kevin Systrom and Maike Krieger to reduce the existing features, so that, they have had to restart from the beginning. Therefore, finally they had been focusing only on the photos, comments and the efforts to like a photo.

b. Some Factors Determining Instagram Social Media as Promotion Media by the users on the Online Shop.

Instagram is one of marketing communication media which has been used the most popular recently, as well as online shop. It should have been some factors that have made online seller or online shop using Instagram as promotion media for their product or service they offer. According to Kiranasari (2013:16). This issue can be connected to the theory described by Kartz, Gurevitch describing Cognitive, affective, personal identity, social identity and entertainment.

1) Cognitive,

2) Affective,

3) Personal Identity,

4) Social Identity,

5) Entertainment.

Besides of the factors described above, there are still some factors influencing it instead of Uses and Gratification such as easy accessability, relative cost, communicative interactive.

1) Easy accessability,

2) Relative cost affordable

3) Lifestyle Envy.

\section{RESEARCH METHOD}

\section{Approach and Type of the Research}

Approach of the Research has applied qualitative approach. It means that the data collected is not in figures, but it has obtained from interview notes, field notes, personal documentation, memos, and other legal documentation. So that, this qualitative research aims to figure out an empirics reality behind the phenomena happened more deeply, in detail and clear. Therefore, applying qualitative approach is to correspond between empirics reality with the applicable theory using descriptive method.

According to McMillan \& Schumacher (in Seojono 2012): Qualitative research is an approach of investigation approach because the researcher has gathered the data by direct face to face meeting and interaction with the people on the research location.

This reseach is descriptive one which is the study describing real circumstances about the object studied, and based on the real condition when the research is on going. According to Sugiyono (2009:21) descriptive method is a method applied to figure out or to analize the result of a research but it is not applied to make an expand conclusion. In other words, descriptive research is a research focusing to the problems as they are during the research. It is descriptive due to its aims to get the explanation objectively.

Restu Hazar and Resista Vikaliana. Analysis of the factors determining social media instragram as promotion media on the online shop in DKI Jakarta area 


\section{Concept of Operasionalization}

According to Sugiyono (2012:31) definition of operational is to define a construct or a character to be studied so that it can be measurable variables. Definition of operational has described the method to be used to perform a research and to operate a construct, so that, other researchers can do replication of measurement using the same method or developing better construct measuring method.

\section{Technique of Data Collection}

Data collection method is a technique or a method to gather the data required by the reseacher. There are some techniques or method of data collection which is usually applied by the researcher. The researcher can apply one or combination of the applicable method according to the problem happened (Kriyantono, 2010:93). This research has applied interview technique.

Interview is a communication for a certain intention. Interview has been done by both parties, interviewer is a person who offer some questions and interviewee which is a person who answers the question offered (Lincoln and Guba in Moleong, 2011:186). This research has applied open standard interview which is using standard questions. The question is using the same questions orderly, and the same method for each respondent.

\section{Informant Selection}

Informant or interviewee is someone who gives or knows the information clearly, or the information resources which is required by the research. The interviewees that are going to be interviewed are as the following:

1. Manager or the owner @elzattahijab as Key Informant for this research, and the main informant is the customer who has purchased the product using online shop @elzattabhijab.

2. Manager or owner @zoyalovers as the Key Informant, and Main informant is the customer who has purchase the product using online shop @zoyalovers.

3. Manager or Owner @rabbaniprofesorkerudung as Key Informant and Main Informant is the customer who has purchased the product using online shop @rabbaniprofesorkerudung. Key Informant of this research is classified

\section{Technique Data Analysis}

In the technique data analysis, we are familiar with Triangulation term. Trilangulation means a technique of data analysis which is combining various data collection technique taken from the available data resources (Sugiyono, 2009:423). Performing triangulation, the researcher has collected the data and data credibility test. In this research data resources collected are not only the owner of online shop, but also the customers who have been purchasing the product via online shop studied.

\section{RESULT AND DESCRIPTION OF THE RESEARCH}

\section{Validity and Reliability of the Research.}

1. Validity and Reliability of Qualitative Research.

Test Validity of the data of the research usually is only focusing on validity and reliability test. This research has had two kinds of research validity which is internal and external validity. . Internal validity is about the accuracy degree of research design and the result achieved. External validity is about the accuracy degree whether the result of the research can be generalized or implemented on the population where the related samples has been taken.

It can be defined that in order to get valid and reliable data of quantitavie research

Restu Hazar and Resista Vikaliana. Analysis of the factors determining social media instragram as promotion media on the online shop in DKI Jakarta area 
is the research itself. But in a qualitative research, the data itself are to be tested. Therefore, Susan Stainback (1988) described that quantitative research has focused on reliability aspect, however, qualitative research has focused on validity aspect.

2. Test of Validity and Reliability of Qualitative Research

Data validity test of qualitative research is using credibility test. Test of credibility and reliability of the result of qualitative data can be done by using triangulation method.

That is why the writer will analyze the data of interview result using Triangulation method. Triangulation is multimethod approach which has been applied by the writer to collect and analyze the data. Fundamental idea is that the phenomena studied can be understood well, and, the extent to which the truth will be obtained when using varied perceptions approach.

The following table is data verification of the interview with Onlineshop managers:

Table 1 Verification of the data of online shop interview.

\begin{tabular}{|c|l|c|c|c|}
\hline No & Requirement category & $\begin{array}{c}\text { Manager } \\
\text { @elzattahijab }\end{array}$ & $\begin{array}{c}\text { Manager } \\
\text { @zoyalovers }\end{array}$ & $\begin{array}{c}\text { Manager } \\
\text { @rabbaniprofesor } \\
\text { kerudung }\end{array}$ \\
\hline 1 & Cognitive & Yes & Yes & Yes \\
\hline 2 & Affective & Yes & Yes & Yes \\
\hline 3 & Personal Identity & Yes & Yes & Yes \\
\hline 4 & Social identity & Yes & Yes & Yes \\
\hline 5 & Entertainment & Yes & Yes & Yes \\
\hline 6 & Accessibility & Yes & Yes & Yes \\
\hline 7 & Relative cost & Yes & Yes & Yes \\
\hline 8 & Life Style Envy & No & No & No \\
\hline
\end{tabular}

The following is data verification of interview result with the customers described on the table as follows:

Table 2. Data verification of interview results with online shop

\begin{tabular}{|c|l|c|c|c|}
\hline No & Requirement Category & $\begin{array}{c}\text { Customer } \\
\text { @elzattahijab }\end{array}$ & $\begin{array}{c}\text { Customer } \\
\text { @zoyalovers }\end{array}$ & $\begin{array}{c}\text { Customer } \\
\text { @rabbaniprofes } \\
\text { orkerudung }\end{array}$ \\
\hline 1 & Cognitive & Yes & Yes & Yes \\
\hline 2 & Affective & Yes & Yes & Yes \\
\hline 3 & Personal Identity & Yes & Yes & No \\
\hline 4 & Social Identity & Yes & Yes & No \\
\hline 5 & Entertainment & Yes & Yes & Yes \\
\hline 6 & Accessibility & Yes & Yes & Yes \\
\hline
\end{tabular}

Restu Hazar and Resista Vikaliana. Analysis of the factors determining social media instragram as promotion media on the online shop in DKI Jakarta area 


\begin{tabular}{|c|l|c|c|c|}
\hline No & Requirement Category & $\begin{array}{c}\text { Customer } \\
\text { @elzattahijab }\end{array}$ & $\begin{array}{c}\text { Customer } \\
\text { @zoyalovers }\end{array}$ & $\begin{array}{c}\text { Customer } \\
\text { @rabbaniprofes } \\
\text { orkerudung }\end{array}$ \\
\hline 7 & Relative Cost & Yes & Yes & Yes \\
\hline 8 & Life Style Envy & Yes & Yes & No \\
\hline
\end{tabular}

\section{Description}

The factors which determine Instagram social media users as online promotion media is corresponding to the theory defined by Katz, Gurevitch, and Hass and the requirement type according to theory of Uses \& Gratification which is: cognitive, affective, personal identity, social identity and entertainment, accessibility, relative cost and Life Style Envy.

Cognitive, Instagram is able to meet cognitive requirement of online seller which is knowledge requirement. Using Instagram, online sellers and online buyers have obtained the knowledge about how to sell their product by applying popular online media, online business, instagram as media sharing lifestyle, and visual branding. Nevertheless, online seller could gain a knowlegde from other online seller thru a certain account.

Affective, is the requirement about like, aesthetic, and experience. Trading in Instagram has got alot of experience either having alot of fun or disappointed. Having alot of fun when they have received many orders, smart buyers, etc. But having alot of disappointed circumstance is when they have been cheated, had impatient buyers, etc. Aethetic experience either by online seller or online buyer happened when visual features and beautiful photos were placed neatly and attractive. The writer has figured out affective factor is one of the factors determining the decision to use Instagram social media as an online promotion media. Each photo or features of the product uploaded into Instagram using good camera and good result will attract the attention of customers and at the end they will purchase the products offered. The most satisfaction experience of online shop is when the customer shares good testimony about the product and the customers will repurchase the product and happy with the product they purchased.

Social identity. Instagram as social media basically is a media to connect one to another person. Online sellers assume that by using Instagram, they will be connected easily to online buyer. Besides that, Instagram has made online seller connect to online shop community which gathers reliable online shops that promote their products on the Instagram account. In this research, the writer has found out the social identity factor is one of the factors determining Instagram as promotion media which is online shop, they are dealing business with other online shop which offering varied product, such as spectacles, handbag, shoes where they are promoting their product on each online shop.

Entertainment. Instagram has fulfilled online seller requirement regarding entertainment (tension released). Instragram is applied not only selling the product, but also for the purpose of entertainment such as enjoying beautiful photos, however, people can stay longer opening Instagram to meet their entertainment need by scrolling timeline and opening photos gallery. It has happened due to content of photos uploaded in Instagram is varied which is about daily life photos, lifestyle, landscape view, holiday, and events.

Accessibility (easy to access). It is one of the factors why online sellers have taken Instagram due to accessibility to Instagram is very easy. Instagram is smartphone application which has been taken every day, so that to access Instagram is very easy and mobile. Instagram is also having the features such as catalogue to ease online buyer looking for the product they needed. It has made the products of online sellers reaching online buyers. This easy accessibily is acknowledged by online buyer.

Restu Hazar and Resista Vikaliana. Analysis of the factors determining social media instragram as promotion media on the online shop in DKI Jakarta area 
Relative Cost/price. Cheaper cost/price is one of the factors for online sellers consideration to choose Instagram as their promotion media, according to them instead of free of charge, promotion in Instagram is more effective and efficient than using posters, billboards, radio even flyers. Using Instagram which is more effective and efficient and free of charge, they could allocate their budget for another purpose. The writer has found out that promotion in Instagram is cheaper, they only need a certain quota of internet, rather than using flyer. In order to attract the intention of customer, sometimes online shop has offered a special discount.

Lifestyle Envy. This circumstance is happened due to people comparing their life with others' lifestyle in Instagram social media. Social media has broken down the separation wall between public figures(actors, artist, mucisian, etc) and the people, now, all the people can see closer the famous people lifestyle. Sometimes, social media has jeopardized the separation wall between celebrities and people, it has happened due to people can package their lifestyle on social media which has put them looking like celebrities. Istagram is able to make ordinary people to be looked like glamourous and expensive people which has made other people jealous. This research has not found out any Lifestyle envy of online sellers, because online sellers believe that their products are having selling value better than other online shops. But, Lifestyle envy has touched the customers or online buyers who have seen alot about the glamourous and expensive lifestyle of the celebrities, so that they look for online shop that is selling the fashion which is similar to the celebrities'fashion they are wearing.

\section{CONCLUSION AND SUGGESTIONS}

Based on the result of reseach data processed, the writer has concluded "Analysis of Factors why Instagram social media users have applied Instagram as Promotion Media on Online shop" as follows:

1. There are 7 of 8 factors influencing Instagram social media users to use it as promotion media which is cognitive, affectives, personal identity, social identity, entertainment, accessibility and relative reasonable cost factors.

2. Lifestyle envy is not one of the factors influencing them to use it as promotion media on their online shop.

3. The researchers has figured out one factor influencing the online shop using Instagram as promotion media which is Insta Stories innovation features and live broadcast. These features are more seen by the customers due to the title of time line Instagram and it has made the online shop easy to promote their product more rapidly.

After having done the research, some suggestions are offered as follow:

1. The owner of online shop should promote their product by paying more atttention to their pictures or photos uploaded and clear description about the price, size and colour. It is expected that online sellers are able to upload the photos which are in compiance with the actual product and detail of the products, so that online buyer will satisfy with the products they purchased.

2 Customers' online shop should be more selective to purchase the product offered. They should be not only interested in the pictures, but also they have to be more accurate. So that, the customers will be satisfied receiving the products they purchased.

3. Further researchers should do a research using the variables of digital communication,media social, and online marketing. They can apply another method to get varied findings. And they are expected to be able to develop more communication science in digital marketing communication.

Restu Hazar and Resista Vikaliana. Analysis of the factors determining social media instragram as promotion media on the online shop in DKI Jakarta area 
The Management Journal of BINANIAGA Vol. 05, No. 01, June 2020

p-ISSN: $2527-4317$, e-ISSN: $2580-149 x$

$6^{\text {th }}$ Accreditation Rating: April 04, 2019-April 03, 2024

\section{REFERENCES}

Alma, Buchari, 2012. Manajemen Pemasaran dan Pemasaran Jasa. Bandung: Alfabeta.

Basu, Swastha dan Irawan. 2008. Manajemen Pemasaran Analisis Prilaku Konsumen. Yogyakarta: Liberti.

Djunadi Ghony, M. dan Almanshur, Fauzan. 2016. Metodologi Penelitian Kualitatif Jakarta: Ar-ruzz Media.

Hurriyati, Ratih. 2008. Bauran Pemasaran dan Loyaliyas Konsumen. Bandung: Alfabeta.

Moelang, Lexy J. 2011. Metode Penelitian Kualitatif. Bandung: Remaja Rosdakarya.

Morrisan, M. A. 2010. Periklanan Komunikasi Pemasaran Terpadu. Jakarta: Kencana.

Nisrina. 2015. Bisnis Online, Manfaat Media Sosial Dalam Meraup Uang. Yogyakarta: Kobis.

Napitupulu, Eko. 2013. Social Media Nation. Jakarta: Prasetya Mulya Publishing.

Puntoadi, Danis. 2011. Menciptakan Penjalan Melalui Social Media. Jakarta: PT. Alex Komputindo.

Sugiyono. 2009. Metode Penelitian Kuantitatif, Kualitatif, dan R\&D. Bandung: Alfabeta.

Tjiptono, G. Chandra. 2008. Pemasaran Strategik. Yogyakarta: Andi.

Kotler, Philip \& Kevin Lane Keller. 2008. Manajemen Pemasaran. Jakarta: Erlangga.

Gumelar, Gumgum. 2016. Pemanfaatan Instagram Sebgai Sarana Promosi oleh Pengelola Industri Kreatif Fashion di Kota Bandung. Bandung: UNIKOM Bandung.

Indhika, R. dan Cindy Jovita. 2017. Media Sosial Instagram sebagai Sarana Promosi untuk Meningkatkan Minat Beli Konsumen. Bandung: Universitas Padjajaran.

Indrawati, Komang Ayu Pradnya, I Nyoman Sudiarta, dan I Wayan Suardana. 2017. Efektivitas Iklan Melalui Media Sosial Facebook dan Instagram Sebagai Salah Satu Strategi Pemasaran di Krisna Oleh-Oleh Khas Bali. Bali: Universitas Udayana Bali.

Restu Hazar and Resista Vikaliana. Analysis of the factors determining social media instragram as promotion media on the online shop in DKI Jakarta area 
The Management Journal of BINANIAGA Vol. 05, No. 01, June 2020

p-ISSN: 2527 - 4317, e-ISSN: 2580 - 149x

$6^{\text {th }}$ Accreditation Rating: April 04, 2019 - April 03, 2024

This page intentionally be emptied.

Restu Hazar and Resista Vikaliana. Analysis of the factors determining social media instragram as promotion media on the online shop in DKI Jakarta area

Page : 22 